\title{
Sunni-centrisme, shia-islamisme og sekterisme
}

Studiet af mellemøstlig islamisme ti år efter de arabiske revolter.

af MORTEN VALBJøRN $\mathcal{E}$ JEROEN GUNNING ennem det seneste årti har der været en omfattende debat om, $\checkmark$ hvordan islamister ${ }^{1}$ har påvirket og selv er blevet påvirket af de store omvæltninger, som Mellemøsten har oplevet siden begyndelsen af de arabiske revolter i 2011. Dette har ikke blot afspejlet sig i utallige studier af islamistiske bevægelser lige fra de ægyptiske, jordanske, syriske, kuwaitiske Muslimske Brødre, Marokkos PJD og alAdl w'al Ihsan og tunesiske an-Nahda over diverse kvietistiske og nyligt politiserede salafistiske grupperinger rundt om i regionen til Jabhat an-Nusra og andre jihadistiske grupper i Syrien, al-Qaida (AO), og ikke mindst Islamisk Stat (IS). Det har ligeledes udmøntet sig i et væld af tematiske diskussioner. De har bl.a. handlet, om de arabiske revolter markerede begyndelsen på en (post)islamistisk æra, ${ }^{2}$ om hvorvidt, hvordan og hvornår inklusion i og eksklusion fra formel politik skaber moderation eller radikaliserer, ${ }^{3}$ om hvor islamisk is egentligt $\mathrm{er}^{4}$ og om islamister kan siges at have en særlig fordel ift. andre akt $\varnothing$ rer, når de stiller op til valg eller er del af en borgerkrig. ${ }^{5}$

Samtidigt har der gennem det seneste tiår også været en mere selvrefleksiv strømning inden for islamisme-forskningen. Den har handlet om, hvorvidt og hvordan omvæltningerne i Mellemøsten har påvirket studiet af mellemøstlig islamisme. Her har nogle anført, at der er behov for en fundamental gentænkning af vore antagelser om islamismen. Det Muslimske Broderskab i Ægypten skulle f.eks. være blevet så fundamentalt forandret, især efter 2013, at tidligere indsigter om deres karakter er af begrænset nytte i dag. Andre har derimod advaret mod at «smide barnet ud med badevandet» under henvisning til, at eksisterende tilgange ved nærmere eftersyn har vist sig fortsat 


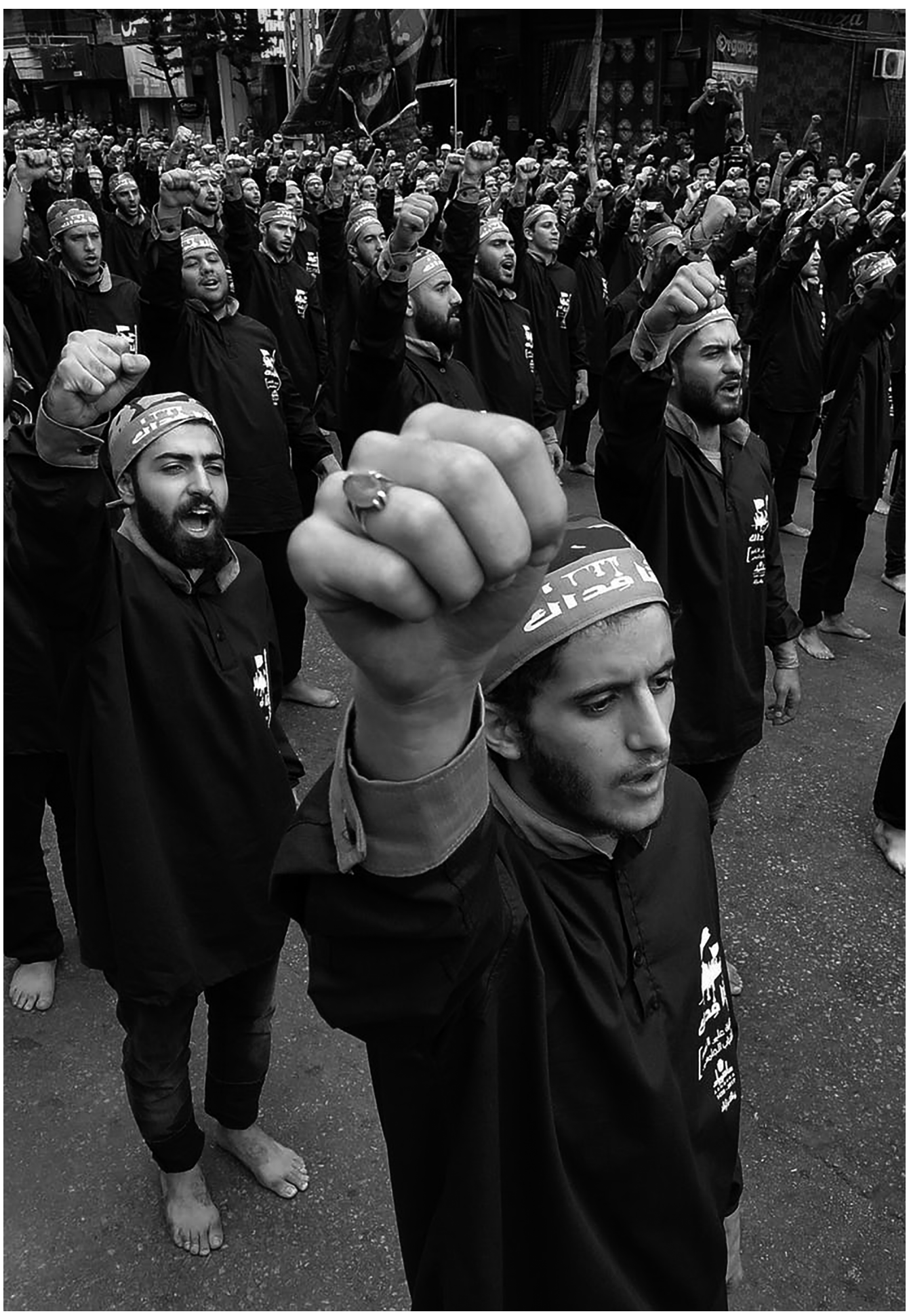


at være ganske nyttige. ${ }^{6}$ Inden for denne selvrefleksive strømning er det muligt at identificere en gryende opmærksomhed omkring en blind vinkel i et ellers stadigt mere sofistikeret og mangefacetteret studie af islamisme. Ved nærmere eftersyn viser store dele af islamisme-debatten sig således traditionelt at have været ganske sunnicentrisk, mens «de andre islamister», altså shiaislamister i diverse varianter, i vidt omfang har været oversete. Det meget mindre forskningsmiljø om disse islamister har endvidere haft sine egne debatter og udviklet sig langs andre analytiske og metodiske spor end den bredere sunni-centriske islamisme-debat, som der har været relativt begrænset interaktion med.

Ikke mindst efter de arabiske revolter synes denne bias i islamisme-forskningen imidlertid at fremstå som stadig mere uholdbar. I de seneste år har der på den baggrund lydt opfordringer til at bringe de andre islamister ind i den bredere islamisme-debat. ${ }^{7}$ Formålet med herværende artikel er at kaste lys over denne gryende interesse for at bringe «de andre islamister» ind i den bredere, men traditionelt sunni-centriske islamisme debat ved at unders $\emptyset$ ge denne strømnings baggrund, udtryk og potentiale. Første del af artiklen retter således fokus på islamisme-forskningens udvikling og diskuterer dels, hvordan den sin vis kan siges at have været relativt snæver, selvom den gennem årene er blevet stadigt mere mange-facetteret, og dels hvorfor «de andre islamister» og shia/sunniskellet gennem det seneste årti er blevet mere synlige og vanskeligere at negligere. I forlængelse heraf undersøger anden del af artiklen, hvorfor og hvordan en større inddragelse af «de andre islamister» har potentiale til at kunne berige den bredere islamisme-debat på flere forskellige måder. Udover at kunne bidrage med nyt empirisk casemateriale i undersøgelser af klassiske tvister og eksisterende hypoteser vedrørende forskellige aspekter ved specifikke former for islamisme, vil en sådan udvidelse af case-universet og en større dialog mellem forskningsmiljøerne omkring sunni-og shia-islamisme således også kunne være med til at rejse helt nye spørgsmål og give velkendte teoretiske tvister et nyt «tvist», og endeligt vil det også kunne give anledning til en mere grundlæggende selv-refleksion vedrørende nogle af de fundamentale meta-debatter, der knytter sig til studiet af islamisme som sådan.

\section{En mange-facetteret, men snæver debat}

Islamisme og forholdet mellem religion og politik har gennem de sidste 50 år haft en særdeles fremtrædende plads på forskningsdagsordenen i studiet af mellemøstlig politik. Det gælder ikke mindst tiden efter 1979 og igen efter 2001. Det seneste årti har imidlertid også været præget af en stor debat om, hvordan islamister har påvirket og selv er blevet påvirket af de store omvæltninger, som fulgte i kølvandet på de arabiske revolter.

Selvom der er skrevet mangt og meget om islamisme, betyder det imidlertid langt fra, at der hersker nogen større enighed eller afklaring om, hvordan man bedst forstår og studerer islamisme. ${ }^{8}$ Det gælder selv det helt basale spørgsmål om, hvad islamisme egentligt er for en størrelse. Med et glimt i øjet har Mozaffari således erklæret, at der er tale om en «URO» forstået som et «uidentificeret religiøst objekt». ${ }^{9}$ Gennem tiden har der f.eks. været investeret mange kræfter $i$ at diskutere, om man bør tale om islamisme, politisk islam, islamisk fundamentalisme eller, som Schwedler seneste har foreslået, forskellige grader af «islamistness». ${ }^{10}$

Det er ligeledes uklart, hvordan islamisme står i forhold til andre omtvistede fænomener som post-islamisme, neo-fundamentalisme og jihadisme. ${ }^{11}$ Der hersker sågar uenighed om, hvorvidt islamister faktisk eksisterer «derude», eller om islamisme snarere bør betragtes som et fænomen «opfundet» af vestlige forskere ligesom orientali- 
ster ifølge Said skabte forestillingen om «Orienten».12

Hvis man er enig med Geertz $\mathrm{i}$, at «progress is marked less by perfection of consensus than by refinement of debate», ${ }^{13}$ betyder den manglende enighed imidlertid ikke, at islamisme-forskningen slet ikke har gjort fremskridt. Når det kommer til spørgsmålet om, hvilken plads islam har i islamismen har debatten således bevæget sig hinsides orientalistisk essentialisme, hvor islamisme reduceres til en islamisk essens, såvel som den form for instrumentalisme, hvor religion opfattes som et rent epifænomen og let ender med at blive forklaret helt væk. I stedet er den aktuelle debat præget af en interesse for, hvordan man kan anerkende, at islam faktisk spiller en rolle for islamister uden samtidigt at essentialisere islam eller ignorere betydningen af andre kontekstuelle faktorer. ${ }^{14}$

$$
\text { ๑๑ }
$$

Ved nærmere eftersyn fremstår den bredere islamisme-debat som overvejende sunnicentrisk, mens shia-islamister har fået begrænset opmærksomhed.

$\odot \odot \odot$

Denne nuancering genfinder man også i, hvordan den klassiske «lumper/splitter»-problematik i de senere år er blevet adresseret. ${ }^{15} \mathrm{Frem}$ for at betragte islamister som ét samlet monolitisk fænomen anerkender de fleste i dag både, at islamisme kan tage mange forskellige former - lige fra anNahda til AQ - og at islamister kan forandre sig over tid og i rum, således som man har set det med det ægyptiske Muslimske Broderskabs tranformation fra al-Bannas oprindelige skepsis over for politiske partier til oprettelsen af Frihed- og Retfærdighedspartiet i 2011. Dette blik for diversitet har ligeledes afspejlet sig i en opmærksomhed omkring, hvordan alle islamister ikke har samme mål, gør brug af vidt forskellige former for aktivisme og har divergerende opfattelser om forhol- det mellem islam og demokrati/nationalisme/vold etc. ligesom de ikke nødvendigvis reagerer ens, hvis de bliver inkluderet eller ekskluderet fra formel politik. Dette har på samme tid affødt en debat blandt «splitters» om, hvordan man bedst kan opdele den islamistiske scene. Simplistiske sondringer mellem radikale versus moderate er således blevet afløst af langt mere sofistikerede, men indbyrdes forskellige typologier, ${ }^{16}$ som i kølvandet på de arabiske revolter igen er blevet revideret. ${ }^{17}$

På den baggrund kan islamisme-debatten på én måde således siges ikke blot at være blevet stadigt mere sofistikeret og nuanceret, men også mangefacetteret og opmærksom på diversiteten på den islamistiske scene. Alligevel kan den samtidigt klandres for traditionelt at have været ganske snæver og behæftet med blinde vinkler. Ved nærmere eftersyn fremstår den bredere islamisme-debat således som overvejende sunni-centrisk, mens shia-islamister i forskellige varianter har fået begrænset opmærksomhed.

Ligesom få sunni-islamister traditionelt har betonet eller reflekteret over, at de er sunni, men primært opfatter sig som islamister som sådan, er denne sunni-bias blandt islamisme-forskere sjældent eksplicit begrundet. Ved at kaste et blik ud over den i andre henseende stadigt mere sofistikerede og mange-facetterede islamisme-forskning vil man imidlertid hurtigt erfare, at interessen især har samlet sig om det Muslimske Broderskabs forskellige forgreninger rundt om i regionen og beslægtede «ikhwanistiske» bevægelser, ${ }^{18}$ om forskellige (kvietistiske, politiske, militante) former for salafisme og om AQ og senest is - alle islamistiske bevægelser, der trods deres store indbyrdes forskelle er fælles om at være sunnitiske.

Hvis man vender blikket mod nogle af de teoretiske debatter vedrørende islamisme, genfinder man denne sunni-centrisme. Det gælder eksempelvis diskussionerne, om islamister har en særlig «electoral advantage», og om hvad der sker, hvis 
de kommer til magten gennem valg, eller den relaterede inklusion/moderations-debat om, hvad der sker med islamister, når de inkluderes i den formelle politiske proces ved at få lov til at stille op til valg mv. ${ }^{19}$ Disse spørgsmål har gennem det seneste tiår - og især i perioden 2011-2013 oplevet en stor fornyet opmærksomhed. Som Patel har peget på, har interessen imidlertid primært samlet sig om erfaringer fra sunni-islamistiske partier, især i Tunesien, Ægypten og Marokko, frem for f.eks. shia-islamistiske partier i Irak, hvis snart tyveårige erfaring med ikke kun at deltage, men også at vinde valg ellers synes oplagt at inddrage. ${ }^{20} \mathrm{I}$ deres diskussion af Heghammers bog om «the rise of global jihad» har Saer El-Jaichi og Mona Sheikh på tilsvarende vis anført, at hans beretning, som de i andre henseender er meget imponeret over, afspejler et «narrow Sunni-centric view», som ensidigt fokuserer på radikale sunnitiske strømninger. Efter deres mening sker det på bekostning af en opmærksomhed omkring andre dele af pan-islamismens ideologiske landskab, herunder om hvilken rolle shiitiske «revivalists» $i$ tiden omkring den iranske revolution spillede for konstruktionen af pan-islamistiske «sensibilities and subjectivities». ${ }^{21}$

Når det kommer til den føromtalte «lumper/splitter»-problematik, viser det sig ligeledes, at de fleste typologier i praksis er - nuancerede og sofistikerede - opdelinger af det sunni-islamistiske landskab. Når specifikke shiaislamistiske grupper faktisk inkluderes, har der meget sigende heller ikke været større interesse for om, hvorvidt - og hvordan - shia/sunni-distinktionen kunne have nogen relevans. Det gælder eksempelvis for Hizballah. I typologi-debatten har den shia-islamistiske bevægelse fra Libanon i reglen været kategoriseret enten som «radikal»/militant og grupperet sammen med både AQ og Hamas, eller - i de mere nuancerede typologier - som et eksempel på «Islamist national resistance» eller «third worldist Islamism» ligesom Hamas (men ikke AO), ${ }^{22}$ selvom de to islamistiske bevægelser på nogle områder er ganske forskellige. ${ }^{23}$ I det omfang doktrinære og ideologiske forskelle har været tilkendt opmærksomhed i denne typologi-debat, har det som oftest snarere handlet om salafi versus ikhwani-distinktionen. ${ }^{24}$ Sunni/shia-sondringen er til gengæld blevet nedtonet, ofte med henvisning til alt, hvad der samler frem for at adskille de to.

\section{De andre islamister}

Selvom den bredere islamisme-debat har været overvejende sunni-centrisk, betyder det hverken, at studier af shia-islamisme har været fuldstændigt fraværende eller at shia/sunni-distinktionen altid har været ignoreret. Især i tiden umiddelbart efter den iranske revolution så man en stor, om end relativt kortvarig interesse for shia-islam(isme), herunder om denne gren af islam(isme) skulle være mere eller mindre politisk, kvietistisk, revolutionær eller militant end den sunnitiske. ${ }^{25}$

I det ganske begrænsede omfang shiaislam(isme) overhovedet havde været tildelt nogen opmærksomhed før 1979, havde der været en generel opfattelse om, at sunni-muslimer var mere aktivistiske, politiske og revolutionære end de angiveligt kvietistiske og apolitiske shia-muslimer. Argumentet $l ø d$, at shia-muslimer ventede på den 12. imams tilbagekomst og i mellemtiden undgik man verdslig politik, idet man angiveligt anså de eksisterende regenter som illegitime. Den shiitiske ulama blev således også betragtet som stort set apolitisk. ${ }^{26}$ Ikke overraskende ændrede denne læsning sig dramatisk efter 1979. Shia-islam blev nu opfattet som en «protest-religion», der nærmest af natur var aktivistisk, politisk og revolutionær. Det blev anført, at den shiitiske forestilling om

Ikke overraskende ændrede synet på den shiitiske ulama som apolitisk sig dramatisk efter 1979. 


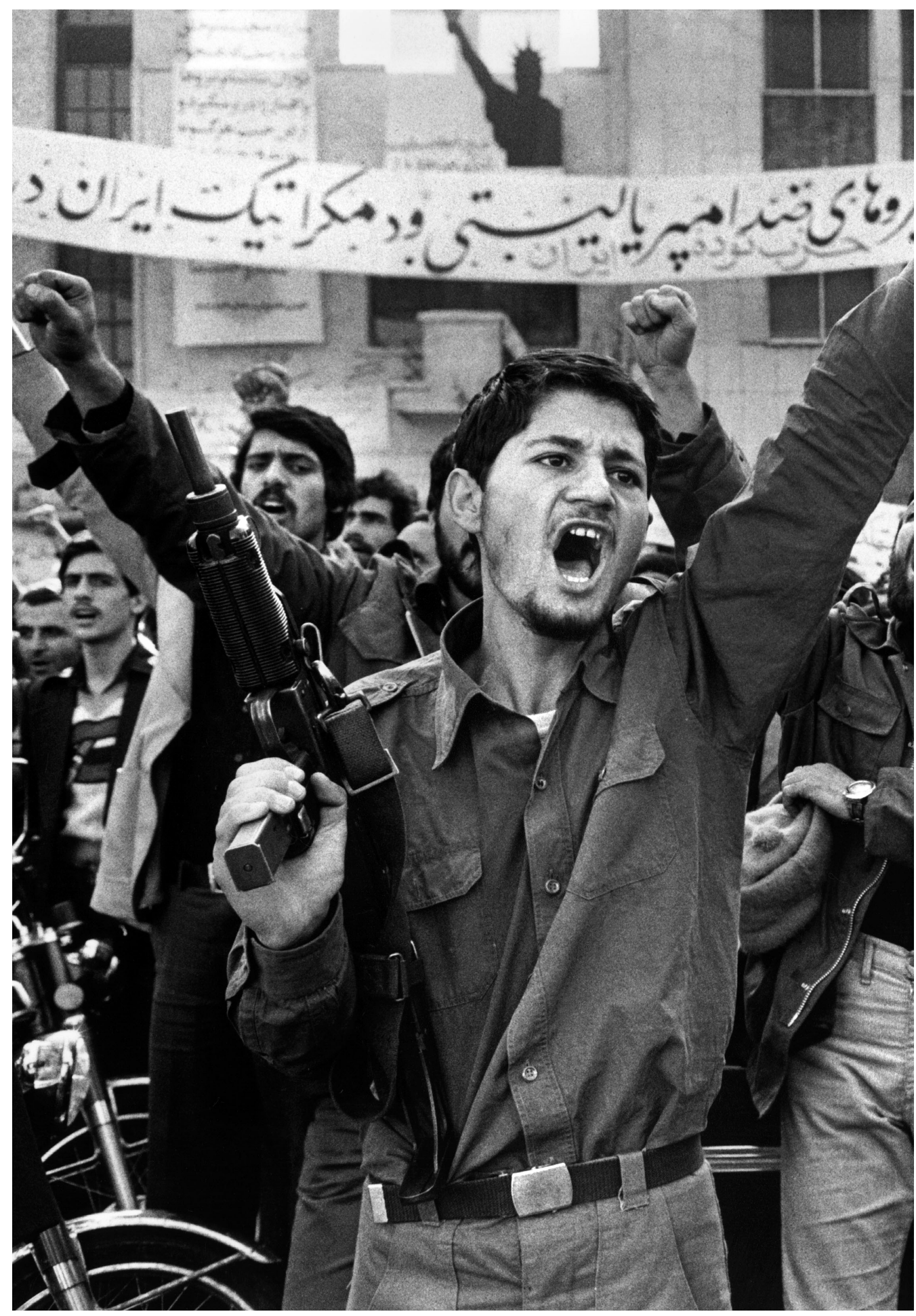


imamatet viste, hvordan religion og politik var bundet uløseligt sammen i shia-islam, ligesom det blev betonet, at Khomeinis ide om velayat-e faqih, som i en vestlig sammenhæn ofte blev beskrevet som et «præstestyre», var rundet af en distinkt shiitisk debat om den ideelle styreform i den 12. imams fravær. På tilsvarende vis blev fortællingen om Husseins martyrium under slaget ved Karbala i 680 fremhævet som et budskab om vigtigheden af at protestere og kæmpe mod uretfærdighed, selv hvis man skal betale den højeste pris. Eller som Kramer formulerede det $\mathrm{i}$ indledningen til bogen Shi'ism, Resistance and Revolution:«when they could Shi' is often rebelled, Islamic history is strewn with Shi'i uprisings». ${ }^{27}$

I den bredere islamisme-forskning aftog interessen for shia-islam(isme) sig dog snart igen, og $\mathrm{i}$ det omfang der var en sådan angik det primært Iran eller Hizballah. ${ }^{28}$ Som Fuller og Francke har peget på, var andre arabiske shia-islamister til gengæld nærmest blevet glemt. ${ }^{29}$ Det bet $\varnothing$ d ikke, at der slet ikke blev forsket i shia-islamisme. Mange af de ellers interessante indsigter, bl.a. om det komplekse samspil mellem sociale, politiske og religiøse faktorer blev imidlertid ikke tildelt større opmærksomhed i den bredere (sunni-centriske) islamisme-debat. ${ }^{30}$ På nær Hamas/Hizballah har der heller ikke været mange komparative studier af shia og sunni-islamistiske bevægelser, og kun få af disse har eksplicit beskæftiget sig med spørgsmålet, om hvorvidt og i givet fald hvordan, hvornår og hvorfor shia/sunni-skellet spiller nogen rolle. ${ }^{31}$

Selvom der altid har været et forskningsmiljø vedrørende shia-islamisme, har det således ikke blot været meget mindre, men ofte også eksisteret parallelt med den bredere (sunni-centriske) islamisme-debat. Som Lynch har peget på, har de to endvidere ofte bevæget sig ad forskellige metodiske og analytiske spor. ${ }^{32}$ På den baggrund er det heller ikke overraskende, at det ikke vakte større genlyd, da International Crisis Group i 2005 opfordrede til ikke blot at skænke «de andre islamister» st $\varnothing r r e$ opmærksomhed, men også at undersøge om, hvorvidt og i så fald hvordan forskellige former for sunni-og shia-islamismer adskiller sig fra hinanden. ${ }^{33}$

\section{Et sekteriseret nyt Mellemøsten}

På sin vis kan den generelle islamisme-forsknings traditionelle snævre fokus på sunni-islamistiske bevægelser og begrænsede opmærksomhed på shia/sunni-sondringen give en vis mening. Demografisk udgør sunni-muslimer en langt større andel af den muslimske befolkninger $i$ verden (omkring 87-9o procent) og i Mellemøsten (omkring 86-89 procent). ${ }^{34}$ På den baggrund er det nærliggende at forvente, at der er langt flere sunniend shia-islamister, og det kan umiddelbart synes mindre overraskende, at førstnævnte har været tilkendt større opmærksomhed. Derudover er det også relevant at erindre sig, at skillelinjen mellem religiøse og sekulære eller vestlige kræfter spillede en langt mere prominent rolle for den tidlige islamisme end shia/sunni-skellet. ${ }^{35}$ Sondringen mellem disse to grene inden for islam blev sjældent direkte adresseret af den moderne islamismes «åndelige (for)fædre» såsom al-Banna og Afghani ${ }^{36}$, og der er mange eksempler på, hvordan shia- og sunni-islamister gennem historien har været gensidigt påvirket. Afghani, som ifølge Keddie havde en shiitisk baggrund og uddannelse, ${ }^{37}$ var med til at plante frøene til nogle af de ideer som senere inspirerede det sunnitiske Muslimske Broderskab og Khomeini oversatte sunnitiske Maududi til farsi, ligesom Muhammed Baqir al-Sadr og shiitiske Hizb al-Dawa i Irak oprindeligt var inspireret af al-Banna. ${ }^{38}$ Mens sunni-islamismen var en kilde til inspiration for nogle af de ideologiske strømninger, der kulminerede med den iranske revolution, gav Khomeinis revolutionære budskab - for en kort stund - genlyd blandt regionens sunni- 
islamister. ${ }^{39}$ Hvis man sammenligner islamistiske bevægelser som Hamas og Hizballah, vil man endvidere finde en visse fællestræk, som til en vis grad gør det meningsfuldt at se dem begge som eksempler på «Islamist national resistance», ${ }^{40}$ ligesom det er nyttigt at erindre sig, hvordan Nasrallah i tiden omkring Sommerkrigen mellem Hizballah og Israel i $2006 \mathrm{n} ø \mathrm{~d}$ stor popularitet i den sunniarabiske verden. ${ }^{41}$

Man kan således opregne mange gode grunde til, at islamisme-forskningen i vidt omfang har koncentreret sig om sunni-islamister, og når det kommer til shia/sunni-skellet, har fokuseret mere på, hvad der samler end adskiller de to grene af islam. Alligevel synes negligeringen af shiaislamister og den begrænsede refleksion over spørgsmålet, om shia-og sunni-islamister på nogen måder adskiller sig fra hinanden, især i de seneste år at være blevet stadigt mere uholdbar. Selvom shia-muslimer udgør et mindretal blandt verdens muslimer, er det værd at erindre sig, at de i Mellemøsten udgør en majoritet i Iran, Irak og Bahrain og en betragtelig befolkningsandel i bl.a. Kuwait, Libanon, Yemen og i mindre grad i Saudi Arabien og Syrien - og endnu vigtigere at man her også finder shia-islamister, hvoraf nogle af disse både er blevet stadigt mere fremtrædende og mere eksplicit «shiitiske» gennem de senere år.

Siden Saddam Husseins fald i 2003 er shiaislamister f.eks. kommet til at spille en ledende rolle i Irak, hvor shia/sunni-spørgsmålet udtrykt i sekterisme også er blevet meget fremtrædende. På den formelle politiske scene har shia-islamistiske partier, som i perioder har mobiliseret omkring sekt-specifikke identiteter, ${ }^{42}$ ikke blot deltaget $\mathrm{i}$ samtlige valg. De har også vundet regeringsmagten i nu snart to årtier, hvilket har udmøntet sig i, hvad Haddad har beskrevet som en shiacentrisk stats-og nationsbygning. ${ }^{43}$ Derudover har Irak gennem to årtier været plaget af voldelige konflikter, som i flere omgange er eskaleret til bor- gerkrige med en stærk sekterisk dimension. Her har militante shia og sunni-islamister, der har betonet deres respektive sekt-specifikke identiteter, har spillet en fremtrædende rolle. ${ }^{44}$

Hvis man retter blikket uden for Irak synes betydningen af shia/sunni-dimensionen især at være blevet mere tydelig i perioden efter 2011, hvor Mellemøsten har oplevet det, som nogle iagttagere har beskrevet som en «sekterisering» af den regionale politik. ${ }^{45}$ Der er tale om et komplekst og tvetydigt fænomen, som ikke blot kan iagttages i holdningerne blandt regionens befolkninger og $\mathrm{i}$ autokratiske regimers brug af «det sekteriske kort», ${ }^{46}$ men også på den «islamistiske scene». Udover at shia-islamister er blevet mere synlige mange steder, er det sekt-centriske aspekt af deres identitet til tider også blevet mere eksplicit. Det gælder også nogle af deres sunni-kolleger, der tidligere som oftest blot opfattede sig selv som «islamister» uden noget præfiks. Denne udvikling er nok mest tydelig de steder, hvor man både finder shia og sunni-islamister, såsom Bahrain, Syrien, Yemen, Irak, Kuwait, Libanon og Saudi-Arabien. Den kan imidlertid også spores i interne rivaliseringer blandt sunni-islamister i eksempelvis Jordan eller gypten, hvor man i de senere år finder en udtalt anti-shiisme trods fraværet af shia-muslimer. ${ }^{47}$

Det seneste tiårs sekterisering af regional politik har også sat sit klare spor i mellemøstforskningen, der nærmest har oplevet sin egen «sekteriske bølge» $\mathrm{i}$ form af et væld af publikationer, der diskuterer sekterismens karakter, årsag og virkning. $4^{8}$ Hvis man derimod vender blikket mod islamismeforskningen, synes den imidlertid fortsat at have en stærk sunni-bias. Meget af diskussionen om, hvordan islamister har påvirket og selv er blevet påvirket af de store omvæltninger, som fulgte i kølvandet på de arabiske revolter og de tilknyttede fors $\emptyset \mathrm{g}$ på at gentænke studiet af islamisme har i vidt omfang fortsat handlet om sunni-islamister, ${ }^{49}$ 
især de ægyptiske Muslimske Brødre, tunesiske anNahda, AQ og Is. Der er ligeledes stadigvæk relativt få fokuserede sammenligninger af shia og sunniislamister, hvor spørgsmålet om betydningen af deres «shia»- og «sunni-ness» tildeles egentlig opmærksomhed. Som allerede nævnt har der på det seneste dog lydt opfordringer til at bringe de andre islamister ind i den generelle, men overvejende sunni-centriske islamisme-debat og enkelte bredere fremstillinger af den mellemøstlige islamisme er på det seneste faktisk begyndt at tildele shia-islamismen er særskilt opmærksomhed. ${ }^{\circ}$ Et eksempel er den seneste tredjeudgave af Utviks Islamismen, som i modsætning til førsteudgaven har et særskilt langt kapitel om shiaislamisme i Iran og den arabiske verden. Det rejser dog spørgsmålet om, hvorvidt og hvordan en større inddragelse af (indsigter fra forskningen om) shia-islamister ville kunne berige den generelle islamisme-debat?

\section{Tre måder at berige islamisme-debaten}

En principiel enighed om, at det er på tide at udvide case-universet i studiet af mellem østlig islamisme og tilkende shia/sunni-dimensionen større opmærksomhed, betyder ikke, at det også står klart, hvorfor og hvordan en større udveksling af indsigter om sunni-og shia-islamisme vil kunne bidrage til den generelle islamisme-debat. Forenklet er det muligt at opregne tre forskellige måder, hvorpå de andre islamister vil kunne berige studiet af mellemøstlig islamisme.

\section{Nyt empirisk input til velkendte tvister}

Den første og mindst vidtgående måde tager afsæt $i$, at en udvidelse af case-universet $i$ form af en større opmærksomhed på shia-islamister vil bidrage med nyt empirisk case-materiale. Det vil kunne være relevant for nogle af de klassiske tvister i islamisme-debatten, hvor nyt materiale måske vil kunne bidrage til at af/bekræfte eksiste- rende hypoteser og antagelser om specifikke aspekter vedrørende forskellige former for islamisme.

Et eksempel kunne være det klassiske spørgsmål om relationen mellem inklusion/moderation og dens tvilling vedrørende eksklusion/radikalisering, som gennem årene har været tildelt stor opmærksomhed i islamisme-debatten. ${ }^{51}$ Siden den oprindelige tese om, at islamister bliver «modereret» ved at blive inkluderet og «radikaliseret» ved at blive ekskluderet, er den simple variant af tesen blevet nuanceret og præciseret på utallige måder. Man har således ivrigt diskuteret om moderation angår holdninger eller adfærd, om det handler om accept af demokrati eller af det eksisterende politiske system, om forskellige former og grader af repression har forskellig effekt, om eksklusion nogle gang også kan skabe moderation, om alle typer aktører reagerer ens på denne samme form for inklusion/eksklusion og endeligt om, hvordan den eventuelle kausalmekanisme mellem f.eks. inklusion og moderation faktisk fungerer.

Gennem det seneste årti har først inklusion/moderations-tesen og især siden 2013 eksklusion/radikaliserings-tesen fået fornyet opmærksomhed..$^{2}$ Det har givet sig til udtryk i en lang række studier især af «the usual suspects» $\mathrm{i}$ form af tunesiske an-Nahda og de ægyptiske muslimske brødre, men også af Ægyptens «politiserede» salafister, Jordans Muslimske Broderskab og marokkanske PJD. Som Patel har bemærket, har Irak imidlertid ikke været tildelt tilsvarende opmærksomhed. Det er overraskende, idet man især ved at vende blikket mod landets shia-islamister vil finde et rigt case-materiale mht. hvordan to årtiers inklusion $\mathrm{i}$ «formel politik» har påvirket islamister. ${ }^{53}$ Som Harith Hasan har peget på har en shia-islamistisk bevægelse som Hizb al-Dawa, der gennem tiden har oplevet eksklusion såvel som inklusion, for eksempel undergået en enorm forandring. Det gælder ikke blot brugen af vold og 
graden af politisk aktivisme, men også mht. hvornår man har mobiliseret omkring en islamistisk ideologi, en shiitisk gruppe-identitet eller mere socio-økonomiske spørgsmål. ${ }^{54}$

En større opmærksomhed på shia-islamistiske partier ikke kun i Irak, men også i Kuwait, Bahrain og Libanon vil også kunne bidrage til andre klassiske diskussioner om islamisme i formel politik. Det gælder f.eks. debatten om islamister har en særlig «electoral advantage».55 De betragtelige erfaringer fra bl.a. shia-islamister i disse lande vil således kunne bidrage med at underbygge eller udfordre konklusioner baseret på indsigter fra gypten og Tunesien. Især Kuwait og Bahrain vil også kunne bidrage til den velkendte diskussion om, hvordan islamistiske partier agerer ved (semi)autokratiske valg, hvor «victory is not an option», herunder om hvordan dette kan skabe splittelse internt i bevægelsen. ${ }^{56}$ De snart tyve års

$$
\odot \odot \odot
$$

Mange sunni-muslimer synes nu at være enige med Qaradawis nedlatende

karakteristik af Hizballah som «hizb alshaytan» (Satans parti). $\odot \odot \odot$

erfaringer med shia-islamistiske partier i den irakiske regering er ligeledes relevant ift. den ofte ganske spekulative debat om, hvad der sker, hvis islamister ikke blot har mulighed for, men faktisk vinder magten gennem valg. Den irakiske scene vil på tilsvarende vis kunne bidrage med nyt case-materiale i debatten om, hvordan man skal betragte islamistiske partier, der har en militant gren, og som stiller op til valg i en kontekst af konflikt. Dette er en problematik, der traditionelt primært har været undersøgt gennem studier af Hamas og Hizballah, men det er oplagt også at rette blikket mod nogle af de aktuelle eksempler på irakiske shia-militser, der deltager i valg. ${ }^{57}$ Hvis man vender blikket mod islamisters rolle i konflikter, vil en udvidelse af case-universet med shia-islamisters ligeledes tilbyde relevant nyt materiale. Det gælder eksempelvis for konflikterne i Syrien, Yemen og Irak, hvor shia-islamister har spillet en central rolle. De vil derfor bl.a. være relevante at inkludere i diskussioner om, der er en særlig «Islamist (dis)advantage at war», herunder om hvorvidt og hvordan vold og religion er forbundet. ${ }^{58}$

\section{Nye teoretiske tvister og gamle tvister med et tvist} Inddragelse af «de andre islamister» kombineret med en større opmærksomhed på shia/sunni-sondringen vil ikke blot give mulighed for at teste eksisterende hypoteser med nyt empirisk materiale. Det vil også kunne give velkendte tvister et anderledes «tvist» og rejse helt nye spørgsmål og hypoteser.

Hvad angår sidstnævnte - nye spørgsmål og hypoteser - har forholdet mellem islamisme og sekterisme traditionelt ikke har været tildelt særlig stor opmærksomhed i islamisme-debatten. På baggrund af det seneste årtis sekterisering af regional politik er det imidlertid nærliggende at spørge om, hvorvidt og hvordan Mellemøstens islamister er blevet påvirket af og selv har påvirket denne udvikling - og hvad det fortæller os om forholdet mellem religion/ideologi og kontekstuelle faktorer for forståelsen af islamisme såvel som sekterisk politik. Det er f.eks. værd at hæfte sig ved, hvordan nogle islamistiske bevægelser gennem de senere har haft en tendens til i højere grad at frame sig selv og/eller deres modstandere i sekt-specifikke kategorier frem for at trække på et mere generelt islamisk symbolunivers. Dette er mest åbenlyst, når syriske og irakiske shia-islamisters gør brug af en distinkt shiitisk referenceramme i deres selvbenævnelse som Kataib al-Imam Ali, Liwa Zulfiqar eller Katibat al-Mahdi al-Muntazar, eller når IS trækker på en lang historisk sekterisk polemik ved nedladende at omtale det irakiske militær eller shiitiske militser som «den safavidiske hær» eller 
som «rejectors» (al-rafida).59 Der findes også mere subtile variationer, $i$ form af hvad man kunne kalde 'anti-sekterisk sekterisme'. Selvom Hizballah i reglen undgår at framme sig selv som distinkt shiitisk, trækker de alligevel på en sekterisk referenceramme, når de erklærer, at shia-muslimer er imod sekterisme samtidigt med, at deres sunnitiske modstandere i den syriske konflikt over en bred kam klassificeres som sekteriske «takfiris». ${ }^{0}$

Udover denne mere eller mindre retoriske brug af en sekterisk referenceramme har de senere års sekterisering også sat sig andre spor på den islamistiske scene, hvor det flere steder er muligt at identificere en form for shia/sunni-skillelinje. Det gælder mest åbenlyst i konfliktzoner som Yemen, Syrien og Irak, hvor shia og sunni-islamistiske militser - med vigtige undtagelser - kæmper på forskellige sider, men også i f.eks. Bahrain, hvor landets sunni-islamister i 2011 loyalt st $\varnothing$ ttede Khalifa-regimet, hvorimod shia-islamister udgjorde en vigtig del af oppositionen, som også talte sunnimuslimske aktivister. ${ }^{61} \mathrm{I}$ den bredere befolkning er det også muligt at iagttage en «sekterisk kløft» i synet på islamister. Mens Hizballah i perioden op til 2011 havde stor folkelig opbakning i mange dele af den sunni-arabiske verden, hvor den shiitiske bevægelse primært syntes at blive opfattet som arabisk, islamistisk og ikke mindst anti-amerikansk/israelsk, indikerer regionale meningsmålinger, at bevægelsen i dag fortrinsvis nyder popularitet blandt shia-muslimer. Mange sunnimuslimer synes derimod nu at være enige med Qaradawis nedladende karakteristik af Hizballah - som han ellers hyldede i 2006 - som «hizb alshaytan» (Satans parti). Det er nærliggende også at se Hizballah og Hamas' vidt forskellige reaktioner på Syrien-konflikten, herunder sidstnævntes brud med den iransk-ledte «modstandsakse» $i$ lyset af denne sekterisering. Samtidigt er det imidlertid også værd at være opmærksom på, hvordan Hamas har fors $\emptyset \mathrm{gt}$ at reetablere de gamle bånd efter, at det er kommet til at stå klart, at 'ikhwanismen' næppe vil blive en dominerende regional faktor i den nærmeste fremtid. ${ }^{62}$

Dette skifte rejser ikke blot spørgsmålet om, i hvilket omfang, hvornår og hvorfor sekterisme synes at påvirke nogle islamistiske bevægelser, f.eks. udtrykt i en forskydning i den relative betoning af deres «islamist-ness» vs. «shia/sunniness». Det giver også anledning til at overveje om, hvorvidt islamister har bidraget mere til de seneste års regionale sekterisering end andre aktører, og om nogle islamister i den forbindelse har spillet en større rolle end andre. I lyset af, at sekterisme på en eller anden måde gerne forbindes med religion, f.eks. shia/sunni sondringen, kunne det, hvad angår det første spørgsmål, være nærliggende at tro, at islamister var mere sekteriske end andre. Ved nærmere eftersyn viser billedet sig imidlertid at være mere kompliceret. Iflg. PEWs surveys om holdninger blandt verdens muslimer er det således ikke muligt at finde nogen entydig sammenhæng mellem holdninger til islamisme og sekterisme, og som Haddad har peget på finder man også «sekulære sekterister» ligesom der er en række eksempler på eksplicit anti-sekteriske islamister, som i retorik og adfærd arbejder på tværs af sekteriske skel. ${ }^{6} \mathrm{Na}$ å det kommer til det andet spørgsmål om forskelle blandt islamister kunne man umiddelbart forvente, at stærke sekteriske holdninger var mere udbredte blandt mere doktrinære varianter af islamisme, således at man blandt sunni-islamister f.eks. ville finde en stærkere anti-shiisme hos salafistiske frem for muslimske brødre eller andre ikhwani-orienterede former for islamisme. Et hurtigt blik over den islamistiske scene efterlader imidlertid et tvetydigt billede. På den ene side er det ikke vanskeligt at finde eksempler på salafister, der bl.a. med inspiration fra ibn Taymiyya og wahhabismen afviser, at shia-muslimer er rigtige muslimer, og til gengæld har det ægyptiske Muslimske Broderskab traditionelt ikke været særligt optaget 
af shia/sunni-sondringen. ${ }^{64}$ På den anden side har det Muslimske Broderskab i Syrien historisk været ganske anti-shiitisk. Hvis man sammenligner Is og $\mathrm{AQ}$, der af iagttagere ofte begge beskrives som «jihadi salafister», finder man endvidere en langt mere udtalt anti-shiisme hos førstenævnte. I sin tid tog AQ ligefrem afstand fra Zarqawis (succesfulde) fors $\emptyset \mathrm{g}$ på at fremprovokere en sekterisk borgerkrig i Irak. ${ }^{65}$

Udover at rejse en række nye spørgsmål vedrørende forholdet mellem islamisme og sekterisme, vil en inddragelse af «de andre islamister» kombineret med en større opmærksomhed på shia/sunni-sondringen også kunne give blik for nye dimensioner ved mere velkendte tvister i islamisme-debatten. Det gælder f.eks. den klassiske debat om islam(isme) og demokrati. Der hersker i dag en generel enighed om, at der findes vidt forskellige holdninger blandt islamister om demokrati som sådan er ønskeligt, og om man bør stille op til valg og være repræsenteret i parlamenter. ${ }^{66}$ Der har imidlertid været mindre opmærksomhed på om eksplicit anti-demokratiske holdninger, hvor elektoral politik kategorisk afvises, primært findes på den sunni-islamistiske scene, således som ICG har hævdet, og i fald dette skulle være tilfældet, om dette bør tilskrives doktrinære forskelle $\mathrm{i}$ shia/sunni islam eller andre faktorer, f.eks. den demografiske forskel mellem shia-og sunni-muslimer. ${ }^{67}$

Når det kommer til den del af debatten om militant islamisme, som angår hvad der ofte betegnes som «global jihadisme», har fokus primært angået sunni-islamistiske bevægelser. Det rejser spørgsmålet, om man i princippet ville kunne forestille sig en shiitisk ækvivalent til AQ eller Is eller er «global jihadisme» et distinkt sunnitisk fænomen, og i givet fald, hvordan vil dette kunne forklares? ${ }^{68}$ I lyset af at transnationalisme også spiller en vigtig rolle inden for den - både militante og ikke-militante-shia-islamisme, ${ }^{69}$ er det endvidere relevant dels at overveje, hvilken rolle shia-islamister, bl.a. i tiden omkring den iranske revolution, har spillet for det pan-islamistiske ideologiske landskab, som den globale jihad også kan ses som en del af, ${ }^{70}$ og dels at undersøge hvilke forskelle og fællestræk man finder mellem transnationale netværk inden for shia og sunni-islamisme, eksempelvis mht. hvilken rolle religiøse autoriteter og institutioner spiller.

Der er også andre dele af debatten om militant islamisme, som vil kunne få et nyt «tvist» ved at blive introduceret for «de andre islamister». Det

$\odot \odot \odot$

I Syrien og Irak ser man således ikke kun sunnitiske, men også shiitiske «fremmed-

krigere» fra blant andet Afghanistan, Pakistan, Libanon og Irak.

๑॰

gælder f.eks. for den klassiske diskussion om forholdet mellem religion og vold, og om hvorvidt og ikke mindst, hvordan islam spiller en rolle for militante islamister, herunder ift. mål, midler, mobilisering, organisering, legitimering etc. ${ }^{71}$ I et komparativt studie af militante shia-islamister fra før de arabiske revolters begyndelse når Moghadam ikke blot frem til, at brug af vold var relativt sjælden blandt shia-islamister og mindre ekstrem end hos visse sunni-islamister. Han konkluderede også, at «there is little that is 'Shii' about 'Shii militancy'» i den forstand, at den sjældent var eksplicit religiøst eller ideologisk motiveret, men snarere drevet af den samme form for politisk utilfredshed, som man også finder hos voldelige ikke-islamistiske grupper. ${ }^{72}$ Hvis man vender blikket mod nogle af de forskellige shia-militser, der har spillet en fremtrædende rolle i f.eks. Irak, Syrien og Yemen, er det på samme tid åbenlyst, at de i deres navngivning og til tider også deres narrativ om konflikterne trækker på et shia-islamisk symbolunivers ligesom de i nogle tilfælde trækker på auto- 
riteter, netværk og organisering og mobiliseringsstrukturer kendt fra en bredere shiitisk tradition. Udover at rejse spørgsmålet om militante shiaislamister siden de arabiske revolters begyndelse har forandret sig og er blevet mere «shiitiske», taler dette også ind i den bredere diskussion, om der er variation blandt islamister ikke blot vedrørende i hvilken grad, men også om hvordan religiøse faktorer spiller en rolle. Et sidste eksempel på, hvordan debatten om militante islamister kan få et «tvist», angår spørgsmålet om, hvordan «fremmedkrigere» (foreign fighters) mobiliseres, og hvad der sker, når de drager hjem. Denne debat strækker sig tilbage til Afghanistan-krigens såkaldte «afghanske arabere», som spillede en central rolle for etableringen af AQ og den såkaldte «globale jihad».73 Ligesom mange andre islamismedebatter har fremmedkriger-debatten traditionelt været meget sunni-centrisk. Gennem de seneste årti har den ikke blot fået fornyet relevans, men har også fået en ny dimension. I Syrien og Irak ser man således ikke kun sunnitiske, men også shiitiske «fremmedkrigere» fra bl.a. Afghanistan, Pakistan, Libanon og Irak. Det rejser en række nye spørgsmål, herunder om de forskellige fremmedkrigere er motiveret og mobiliseres på samme måde, om der er forskelle i den rolle lokale og regionale aktører spiller, og om indsigter fra den klassiske debat om hjemkomne (sunnitiske) fremmedkrigere kan bruges til at forstå, hvad der sker «when Ali comes marching home». ${ }^{74}$

\section{Genovervejelse af klassiske meta-debatter}

Udover at bidrage enten med nyt empiriske materiale eller med nye dimensioner eller «tvister» til debatter om specifikke aspekter ved forskellige former for islamisme, vil en udvidelse af «case-universet» også kunne give anledning til en mere grundlæggende selv-refleksion vedrørende nogle af de fundamentale meta-debatter, der knytter sig til studiet af islamisme som sådan.
Det gælder f.eks. det basale, men fortsat omtvistede spørgsmål om, hvad islamisme egentligt er for en størrelse, udover at være en URo. Med andre ord hvordan definerer man meningsfuldt islamisme på en måde, der på den ene side dækker hele spektret fra al-Qaida til an-Nahda og på den anden side gør det muligt at sondre mellem islamister og ikke-islamister, især i en kontekst, hvor vidt forskellige politiske aktører, herunder regimer og opposition, trækker på en islamisk referenceramme. Gennem tiden har det været utallige bud på, hvordan dette spørgsmål kan besvares. For nogle er en islamist en person, «who believes that Islam as a body of faith has something important to say about how politics and society should be ordered»,75i hvilket betyder, at f.eks. også den jordanske konge bør anses som islamist. Andre derimod ser islamisme som «a religious ideology with a holistic interpretation of Islam whose final aim is the conquest of the world by all means». ${ }^{76}$ Det vil imidlertid indebære, at de mange islamister, der afviser brugen af vold, og ikke-militante såvel som militante, der udelukkende er orienteret mod et afgrænset territorium, ikke opfattes som islamister. Et fællestræk hos mange af forsøgene på at karakterisere islamismen er imidlertid en betoning af, at selvom islamister $\varnothing$ nsker en form for islamisering af samfundet og staten, så er de skeptiske til de gejstlige autoriteter, ulamaen, der ses som forstokket. Det betones således gerne, at islamismen i vidt omfang er en moderne lægmandsbevægelse, der frem for gejstlige populært sagt har været anført af læger, lærere og ingeniører (jf. Hassan alBanna, Sayyid Qutb, Ayman al-Zawahiri, Usama bin Ladin) og kendetegnet ved, hvad Roy i sin tid beskrev som en «islamistisk antiklerikalisme». ${ }^{77}$

Denne karakteristik af islamismen skal givetvis ses i lyset af, hvordan mange tager afsæt i det ægyptiske Muslimske Broderskab, som ofte beskrives som en «prototypisk islamistisk bevægelse», således som Mandaville udtrykker det. ${ }^{8}$ Dette rejser 
imidlertid spørgsmålet, om denne karakteristik er mere dækkende for sunni-end shia-islamister? I modsætning til Roys «antiklerikalisme», beskriver Louër således shia-islamismen som en «clerical ideology», hvor ulamaen historisk har været meget prominent, ${ }^{79}$ jf. den ledende rolle gejstlige personer såsom Muhammed Baqir al-Sadr, Muhammad Sadiq al-Sadr, Musa al-Sadr, Mohammad Hussein Fadlallah, Ruhollah Khomeini og Mohammad alShirazi har spillet. Dette afspejler sig også i visionen om en islamisk stat. Selvom både sunni- og shia-islamister har haft en sådan, bemærker Louër, at sidstnævnte i modsætning til førstnævnte nærmest har været «obsessed with the question of institutionalizing the ulama's role in government» ${ }^{80}$ En anden forskel, som fremhæves i ICGs føromtalte rapport fra 2005, er, at den shia-islamistiske scene skulle være mere integreret end den mere fragmenterede sunni-islamistiske. I det omfang dette faktisk (fortsat) skulle være tilfældet, melder der sig imidlertid et spørgsmål om dette skal tilskrives den demografiske forskel mellem shia og sunnimuslimer eller mere doktrinære forhold. ICG tillægger således de forskelligartede syn på ijtihad inden for shia og sunni-islam en central rolle både for forskellen i de gejstlige rolle inden for shia og sunni-islamisme og for graden af fragmentering inden for de to islamistiske scener. ${ }^{81}$

Hvis man er enig med ICG om, at det er nødvendigt at «distinguish between Shiite and Sunni Islamism», som ifølge rapporten står «in stark contrast», og deler Louërs opfattelse om, at shiaog sunni muslimer hver har produceret deres egen version af islamisme ${ }^{82}$ melder der sig endnu en række nye spørgsmål som islamisme-debatten traditionelt ikke har tildelt større opmærksomhed.

Et af disse handler om, hvordan man kan definere islamisme på en måde, som har blik for, hvad sunni-og shia-islamister faktisk er fælles om frem for at tage afsæt i en «proto-typisk sunnitisk islamistisk bevægelse». Et andet spørgsmål drejer sig ikke blot om hvordan, men også om i hvilken grad og i hvilken sammenhæng, der er substantielle forskelle mellem sunni-og shia-islamister. Hvis både religion, ideologi og den politiske kontekst er med til at forme specifikke islamistiske bevægelser kunne man forestille sig at shia-og sunni-islamister i nogle sammenhænge eller på nogle tidspunkter har mindet mere eller mindre om hinanden end andre. F.eks. vil det være relevant at sammenligne sunni-og shia-islamistiske politiske partier, der har mulighed for at deltage i valg og sidde $\mathrm{i}$ parlamenter, med sunni-og shia-islamister, som er del af nogle af de aktuelle borgerkrige for at undersøge forskelle og fællestræk ikke blot mellem shia og sunni-islamister i den samme kontekst, men

๑๑

Denne debat strækker sig tilbake til Afghanistan- krigens såkaldte «afghanske arabere» som spillede en central rolle for etableringen av al-Qaida.

๑॰

også indbyrdes mellem hhv. shia og sunni-islamister i forskellige kontekster. Dette knytter an til et tredje spørgsmål, som er relateret til den tidligere omtalte «lumper/splitter»-debat. Der er i dag en basal enighed om, at det er vigtigt at sondre mellem forskellige former for islamisme, og der findes et væld af bud på, hvordan en islamisme-typologi kan se ud. I realiteten er de fleste af disse imidlertid typologiseringer af sunni-islamistiske bevægelser og hverken shia/sunni-sondringen eller shia-islamistiske bevægelser er almindeligvis tildelt større opmærksomhed. Dette gælder også for nogle af de reviderede eller helt nye typologier, som forandringer på den (sunni)islamistiske scene efter 2011 har givet anledning til. ${ }^{83}$ Det er således ikke klart, hvordan «de andre islamister» bedst integreres $\mathrm{i}$ den eksisterende typologi-debat. Såfremt der er behov for at sondre mellem forskellige former for 
shia-islamisme - ligesom det gælder for sunniislamismen - kan man så blot indplacere konkrete shia-islamistiske bevægelser i en eksisterende typologi, selvom den er lavet på basis af sunniislamister; skal man i stedet fors $\emptyset$ ge at lave en distinkt typologi for forskellige shia-islamismer eller er der snarere behov for en fundamental gentænkning af hele typologi-problematikken - og studiet af mellemøstlig islamisme som sådan?

\section{Konklusion}

Ligesom Mellemøstens islamistiske scene har den akademiske islamisme-debat ikke været upåvirket af det seneste tiårs mange omvæltninger i regionen. Udover at give anledning til en større diskussion om hvorvidt og hvordan islamister har påvirket og selv er blevet påvirket af de arabiske revolter og deres efterspil, har dette afspejlet sig i en mere selv-refleksiv strømning. Den har kredset omkring spørgsmålet om, hvorvidt og hvordan det er nødvendigt at gentænke studiet af mellemøstlig islamisme. Herværende artikel har indskrevet sig i og fors $\varnothing$ gt at bidrage til denne problematik. Det er sket ved at vise, hvordan det traditionelle studie af islamisme har været relativt sunni-centrisk, om end dette sjældent har været ekspliciteret eller begrundet, og samtidigt pege på en voksende anerkendelse af, at det bl.a. som følge af det seneste tiårs sekterisering af regional politik er nødvendigt at tildele shia-islamister og shia/sunni-skellet større opmærksomhed. Udover at kortlægge denne udvikling, har artiklen endvidere diskuteret, hvordan en sådan udvidelse af det islamistiske case-univers ikke kun vil kunne skabe større viden om «de andre islamister», men har også potentialet til på forskellig vis at kunne bidrage til at gøre det generelle studie af mellemøstlig islamisme yderligere sofistikeret og mange-facetteret.

$$
\cdot f \cdot
$$

1 Som det vil fremgå er studiet af islamisme præget af stor diversitet og uenighed, herunder om hvordan man skal definere islamisme og karakterisere dets relation til beslægtede begreber som jihadisme, salafisme, (neo)fundamentalisme, post-islamisme mv., og hvem der på den baggrund skal regnes som islamister. Én mulig måde at forholde sig til denne diversitet på er at starte med at udvælge en enkelt specifik og snæver definition og se bort fra de mange $\varnothing$ vrige, og f.eks. sondre mellem islamister, salafister og jihadister. Da et af artiklens ærinder netop er at unders $\emptyset$ ge forskellige forståelser af, hvad der karakterer islamisme og deres implikationer for studiet af islamisme, jf. Gallies klassiske diskussion om 'essentially contested concepts', har vi imidlertid valgt en anden strategi, hvor vi bevidst nøjes med at tage afsæt $\mathrm{i}$ en bred og meget rummende forståelse af, hvad vi forbinder med islamisme. Nærmere bestemt ser vi - med inspiration fra bl.a. Esposito og ICG - islamisme som en moderne politisk ideologi forbundet med social/politisk aktivisme optaget af implementeringen af en given ideologisk vision af islam i stat/samfund. Inden for denne meget brede kategori, hvor islamisme er en slags paraplybegreb, finder man vidt forskellige former for islamisme. Nogle deltager i formel politik, mens andre afviser denne, ligesom brugen af vold glorificeres af nogle og afvises af andre. Ligesom mange andre anerkender vi således at der er behov for en yderligere underkategorisering, men frem for at indlede med at præsentere en bestemt typologi, diskuterer artiklen forskellige bud på typologier og identificerer nogle af de udfordringer en sådan typologisering er kendetegnet ved. I forlængelse af vor brede forståelse af islamisme ser vi heller ikke jihadisme eller salafisme, som stående i kontrast til islamismen, som det til tider er tilfældet, men snarere som strømninger inden for islamismen. Om 'essentially contested concepts' se Gallie, W. B., Essentially Contested Concepts, Proceedings of the Aristotelian Society 56 (1956).

2 Roy, O., «This Is Not an Islamic Revolution», New Statesman, February 15, 2011, newstatesman.com/ religion/2011/o2/egypt-arab-tunisia-islamic; Bayat, A., ed. Post-Islamism - the Many Faces of Political Islam (Oxford: Oxford University Press, 2013).

3 Wuthrich, F. M. and S. Ciftci, Islamist Parties, Intraparty Organizational Dynamics, and Moderation as Strategic Behaviour, Mediterranean Politics (2020).

4 Cottee, S., "What Isis Really Wants” Revisited: Religion Matters in Jihadist Violence, but How?, Studies in Conflict \& Terrorism 40, no. 6 (2017).

5 Cammett, M. and P. J. Luong, «Is There an Islamist Political Advantage?», Annual Review of Political Science 17, no. 1 (2014); Lynch, M., «Is There an Islamist Advantage at War?», APSA MENA Politics Newsletter 2, no. 1 (2019).

6 Masoud, T., «Rethinking Political Islam? Think Again», POMEPS Studies, no. 6 (Rethinking Islamist Politics) (2014); Yadav, S. P., «Progressive Problemshift or Paradigmatic Degeneration? Approaches to Islamism since 2011», ibid.; Hegghammer, T., Jihadism: Seven 
Assumptions Shaken by the Arab Spring, ibid.; Lynch, M. and J. Schwedler, Introduction to the Special Issue on "Islamist Politics after the Arab Uprisings", Middle East Law and Governance 12, no. 2 (2020); Hamid, S. and W. F. McCants, eds., Rethinking Political Islam (New York, NY, USA: Oxford University Press, 2017).

7 Valbjørn, M. and J. Gunning, «Bringing in the 'Other Islamists': Beyond Sunni-Centric Islamism Studies in a Sectarianized Middle East», Mediterranean Politics (2020); Valbjørn, M., «Bringing the 'Other Islamists' Back In: Sunni and Shia Islamism(S) in a Sectarianized New Middle East», POMEPS Studies, no. 28 (New Analysis of Shia Politics) (2017); Patel, D. S., «The Marginalization of Iraqi Islamists in Political Science, APSA MENA Politics Newsletter 2, no. 1 (2019); POMEPS, «New Analysis of Shia Politics», in POMEPS Studies (2017).

8 For en oversigt over, hvordan man inden for forskellige discipliner har tilnærmet sig islamisme som en analytisk kategori, se Volpi, F., Political Islam Observed (London: Hurst, 2010).

9 Mozaffari, M., «What Is Islamism? History and Definition of a Concept», Totalitarian Movements and Political Religions 8, no. 1 (2007).

10 Schwedler, J., «Conclusion: New Directions in the Study of Islamist Politics», in Islamists and the Politics of the Arab Uprisings: Governance, Pluralisation and Contention, ed. H. Kraetzschmar and P. Rivetti (Edinburgh: Edinburgh University Press, 2018).

11 Roy, O., «Skakmat. Politisk islam: Et alternativ for de muslimske samfund? (København: Eirene, 1993); Wagemakers, J., «Making Definitional Sense of Islamism», Orient, no. II (2021); Cesari, J., «Political Islam: More Than Islamism», Religions 12, no. 5 (2021); Ismail, S., «The Paradox of Islamist Politics», Middle East Report, no. 221 (2001); Mandaville, P., «Is the PostIslamism Thesis Still Valid?», POMEPS Studies, no. 6 (Rethinking Islamist Politics) (2014).

12 Volpi, Political Islam Observed, 8.

13 Geertz, C., The Interpretation of Cultures (London: Fontana Press, 1993), 29.

14 Gunning, J., «Like Two Peas in a Pod or Two Roads Diverging? Comparing Hamas and Hizballah», Mediterranean Politics (2020); Eickelman, D. F. and J. Piscatori, Muslim Politics (New Jersey: Princeton University Press, 1996).

15 Lynch, M., «The Lumpers and the Splitters», POMEPS Studies, no. 26 (Adaptation Strategies of Islamist Movements) (2017).

16 F.eks. Hegghammer, T., «Jihadi-Salafis or Revolutionaries? On Religion and Politics in the Study of Militant Islamism» in Global Salafism-Islam's New Religious Movement, ed. R. Meijer (London: Hurst \& Co, 2009); International Crisis Group, «Understanding Islamism» i ICG Middle East Report (2005); Dalacoura,
K., «Islamist Terrorism and the Middle East Democratic Deficit: Political Exclusion, Repression and the Causes of Extremism», Democratization 13, no. 3 (2006).

17 F.eks. Stenersen, A., «Jihadism after the 'Caliphate': Towards a New Typology», British Journal of Middle Eastern Studies 47, no. 5 (2020); González Mendelejis, N., «Toward a New Typology of Sunni Jihad», Studies in Conflict \& Terrorism 43, no. 12 (2020); Hafez, M., «The Crisis within Jihadism: The Islamic State's Puritanism Vs. Al-Qaida’s Populism», CTC Centinel 13, no. 9 (September) (2020); Wagemakers, Making Definitional Sense of Islamism.

18 Om 'ikhwanisme’ forstået som islamistiske bevægelser, der har været inspireret af det Muslimske Broderskab, men som sådan ikke er del af broderskabsbevægelsen se Mandaville, P., Islam and Politics (New York: Routledge, 2020).

19 Schwedler, J., «Can Islamists Become Moderates?: Rethinking the Inclusion-Moderation Hypothesis», World Politics 63, no. 2 (2011); Cammett and Luong, «Is There an Islamist Political Advantage?».

20 Patel Patel, «The Marginalization of Iraqi Islamists in Political Science».

21 Hegghammer, T., The Caravan:Abdallah Azzam and the Rise of Global Jihad (Cambridge: Cambridge University Press, 2020); El-Jaichi, S. and M. K. Sheikh, «Explaining the Rise of Global Jihad», Journal of Religion and Violence 8 , no. 2 (2020).

22 F.eks. Ayoob, M. and D. N. Lussier, The Many Faces of Political Islam: Religion and Politics in the Muslim Societies (Ann Arbor: University of Michigan Press, 2020); Strindberg, A. and M. Wärn, «Realities of Resistance: Hizballah, the Palestinian Rejectionists, and Al-Qaida Compared», Journal of Palestine Studies 34, no. 3 (2005); Fettweis, C. J., «Freedom Fighters and Zealots: Al Qaeda in Historical Perspective», Political Science Quarterly 124 (2009).

23 Daher, A., «Shi' ism, National Belonging and Political Islam: The Hezbollah and the Islamic Resistance in Lebanon», in Political Parties in the Arab World: Continuity and Change, ed. F. Cavatorta and L. Storm (Edinburgh: Edinburgh University Press, 2018); Gunning, «Like Two Peas in a Pod or Two Roads Diverging? Comparing Hamas and Hizballah».

24 F.eks. Utvik, B. O., Islamismen (Oslo: Unipub, 2011).

25 McEoin, D., «Aspects of Militancy and Quietism in Imami Shi'ism», British Society for Middle Eastern Studies. Bulletin 11, no. 1 (1984); Kramer, M., ed. Shi'ism, Resistance, and Revolution (London: Mansell, 1987); Keddie, N., Religion and Politics in Iran: Shi' ism from Quietism to Revolution (New Haven: Yale University Press, 1983).

26 For et overblik over denne debat se Kalantari, M. R., «The Shi'i Clergy and Perceived Opportunity Structures: Political Activism in Iran, Iraq, and Lebanon», British 
Journal of Middle Eastern Studies 48, no. 2 (2021).

27 Kramer, Shi'ism, Resistance, and Revolution.

28 Daher, A., Hezbollah: Mobilisation and Power (London: Hurst, 2019); Saouli, A., Hezbollah: Socialization and Its Tragic Ironies (Edinburgh: Edinburgh University Press, 2019).

29 Fuller, G. E. and R. R. Francke, The Arab Shi' $a$ : The Forgotten Muslims (New York: St. Martin s Press, 1999).

30 Blandt undtagelserne Matthiesen, T., The Other Saudis Shiism, Dissent and Sectarianism (Cambridge: Cambridge University Press, 2015); Moghadam, A., ed. Militancy and Political Violence in Shiism: Trends and Patterns (NY: Routledge, 2011); Louër, L., Transnational Shia Politics (NY: Columbia University Press, 2008).

31 Blandt undtagelserne Dingel, E., Power Struggles in the Middle East: The Islamist Politics of Hizbullah and the Muslim Brotherhood (London: I. B. Tauris, 2016); Koss, M., Resistance, Power, and Conceptions of Political Order in Islamist Organizations: Comparing Hezbollah and Hamas (London: Routledge, 2018); Gunning, «Like Two Peas in a Pod or Two Roads Diverging? Comparing Hamas and Hizballah».

32 Lynch, M., «Introduction», POMEPS Studies, no. 28 New Analysis of Shia Politics (2017).

33 International Crisis Group, «Understanding Islamism».

34 PEW Research Center, «Mapping the Global Muslim Population», in PEW Forum on Religion \& Public Life (2009).

35 Louër, L., Sunnis and Shi'a: A Political History of Discord (Princeton: Princeton University Press, 2020).

36 Hamid, S., «The Lesser Threat: How the Muslim Brotherhood Views Shias and Shiism», Mediterranean Politics (2020).

37 Keddie, N., «Sayyid Jamal Al-Din Al-Afghani», in Pioneers of Islamic Revival, ed. A. Rahnema (London: Zed Books, 1994). Det skal bemærkes, at Afghanis baggrund er stærkt omdiskuteret, herunder om han var afghansk sunni-muslim eller en iransk shia-muslim med en shiitisk uddannelse fra både Iran og Irak.

38 Louër, Sunnis and Shi'a: A Political History of Discord; Bohdan, S., «They Were Going Together with the Ikhwan: The Influence of Muslim Brotherhood Thinkers on Shi'i Islamists During the Cold War», The Middle East Journal 74, no. 2 (2020).

39 Ataie, M. et al., «How Iran's 1979 Revolution Affected Sunni Islamists in the Middle East», LSE Middle East Centre, blog, April 26, 2021, blogs.lse.ac.uk/mec/ 2021/04/26/how-irans-1979-revolution-affected-sunniislamists-in-the-middle-east/.
40 Ayoob and Lussier, The Many Faces of Political Islam: Religion and Politics in the Muslim Societies.

41 Valbjørn, M. and A. Bank, «The New Arab Cold War: Rediscovering the Arab Dimension of Middle East Regional Politics», Review of International Studies 38 , no. 1 (2012).

42 Edwards, S. A., «Sectarian Friction and the Struggle for Power: Party Politics in Iraq Post-2003», in Political Parties in the Arab World: Continuity and Change, ed. F. Cavatorta and L. Storm (Edinburgh: Edinburgh University Press, 2018).

43 Haddad, F., Understanding 'Sectarianism': Sunni-Shi'a Relations in the Modern Arab World (London: Hurst Publishers, 2020).

44 Steinberg, G., «Jihadi-Salafism and the Shi' is: Remarks About the Intellectual Roots of Anti-Shi ism», in Global Salafism. Islam's New Religious Movement, ed. R. Meijer (London: Hurst \& Co, 2009); Hassan, H., «The Sectarianism of the Islamic State - Ideological Roots and Political Context», in Carnegie Endowment for International Peace (2016).

45 Hashemi, N. A. and D. Postel, eds., Sectarianization: Mapping the New Politics of the Middle East (London: Hurst Publishers, 2017).

46 Valbjørn, M. and R. Hinnebusch, «Playing 'the Sectarian Card' in a Sectarianized New Middle East», Babylon Nordic Journal for Middle East Studies 16, no. 2 (2018).

47 Saleh og Kraetzschmar 2015, Wagemakers 2020 Saleh, A. and H. Kraetzschmar, «Politicized Identities, Securitized Politics: Sunni-Shi'a Politics in Egypt», Middle East Journal 69, no. 4 (2015); Wagemakers, J., «Making Sense of Sectarianism without Sects: Quietist Salafi Anti-Shia Discourse in Jordan», Mediterranean Politics (2020).

48 For et overblik over denne debat, se Valbjørn, M. «Observing (the Debate on) Sectarianism: On Conceptualizing, Grasping and Explaining Sectarian Politics in a New Middle East», ibid., no. first-view (2021).

49 Hamid and McCants, Rethinking Political Islam.

50 Et eksempel er den seneste tredjeudgave af Utviks Islamismen, som i modsætning til førsteudgaven har et særskilt langt kapitel om shia-islamisme i Iran og den arabiske verden. Utvik, B. O., Islamismen (Bergen: Bergen Fagbokforlaget, 2020).

51 For et overblik se Schwedler, «Can Islamists Become Moderates?: Rethinking the Inclusion-Moderation Hypothesis».

52 Schwedler 2017 «Why Exclusion and Repression of Moderate Islamists Will Be Counterproductive», POMEPS Studies, no. 26 (Adaptation Strategies of Islamist Movements) (2017). 
53 Patel Patel, «The Marginalization of Iraqi Islamists in Political Science».

54 Hasan, H., «From Radical to Rentier Islamism: The Case of Iraq's Dawa Party», Diwan: Carnegie Middle East Center, April 16, 2019, carnegie-mec.org/2019/04/16/ from-radical-to-rentier-islamism-case-of-iraq-s-dawaparty-pub-78887.

55 Cammett and Luong, «Is There an Islamist Political Advantage?».

56 Brown, N., When Victory Is Not an Option - Islamist Movements in Arab Politics (Ithaca: Cornell University Press 2012).

57 Calculli, M., «Between the Battlefield and the Ballot Box: Armed Political Parties in the Middle East», in Routledge Handbook on Political Parties in the Middle East and North Africa, ed. F. Cavatorta, L. Storm, and V. Resta (London: Routledge, 2020); Rudolf, I., «From Battlefield to Ballot Box: Contextualising the Rise and Evolution of Iraq's Popular Mobilisation Units», in ICSR Report (2018).

58 Lynch, «Is There an Islamist Advantage at War?»; Valbjørn, M. and J. Gunning, «Islamist Identity Politics in Conflict Settings», ibid.3 (2020).

59 Anzalone, C., «In the Shadow of the Islamic State: Shi'i Responses to Sunni Jihadist Narratives in a Turbulent Middle East», in Jihadism Transformed:Al-Qaeda and Islamic State's Global Battle of Ideas, ed. S. Staffell and A. N. Awan (Oxford: Oxford University Press, 2016).

6o Malmvig, H., «Allow Me This One Time to Speak as a Shi'i: The Sectarian Taboo, Music Videos and the Securitization of Sectarian Identity Politics in Hezbollah's Legitimation of Its Military Involvement in Syria», Mediterranean Politics 26, no. 1 (2021); Saade, B., «Hezbollah and Its Takfiri Enemy in Syria: Rethinking Relations between States and Non-State Actors», in The Middle East and North Africa between Regional Autonomy and International Intervention, ed. R. A. Boserup, et al. (Copenhagen/Beirut: DIIS/AUB, 2017).

61 Matthiesen, T., Sectarian Gulf: Bahrain, Saudi Arabia, and the Arab Spring That Wasn't (Stanford, California: Stanford University Press, 2013).

62 Koss, M., Flexible Resistance: How Hezbollah and Hamas Are Mending Ties, Diwan: Carnegie Middle East Center, no. July 11 (2018).

63 Haddad, F., Secular Sectarians, MEI - Analysis and Opinion, June 17, 2014, 2014, mei.edu/publications/secular-sectarians.

64 Hamid, The Lesser Threat: How the Muslim Brotherhood Views Shias and Shiism.

65 Steinberg, «Jihadi-Salafism and the Shi'is: Remarks About the Intellectual Roots of Anti-Shi'ism»; Hafez, «The Crisis within Jihadism: The Islamic State's Puritanism Vs. Al-Qaida’s Populism».
66 Esposito, J. et al., eds., Islam and Democracy after the Arab Spring (Oxford: Oxford University Press, 2016).

67 International Crisis Group, «Understanding Islamism»; enstead, L., «Why Some Arabs Don’t Want Democracy», Washington Post, The Monkey Cage, September 30, 2014, washingtonpost.com/blogs/monkeycage/wp/2014/o9/30/why-some-arabs-dont-wantdemocracy

68 Robinson, G. E., Global Jihad: A Brief History (Redwood City: Stanford University Press, 2020).

69 Louër, Transnational Shia Politics.

70 El-Jaichi and Sheikh, «Explaining the Rise of Global Jihad».

71 Valbjørn and Gunning, «Islamist Identity Politics in Conflict Settings».

72 Moghadam, Militancy and Political Violence in Shiism: Trends and Patterns.

73 Hegghammer, The Caravan:Abdallah Azzam and the Rise of Global Jihad; Robinson, Global Jihad: A Brief History.

74 Reiff Reiff, J. C., «When Ali Comes Marching Home: Shi'a Foreign Fighters after Syria», Studies in Conflict \& Terrorism 43, no. 11 (2020).

75 Fuller i Volpi, Political Islam Observed.

76 Mozaffari, «What Is Islamism? History and Definition of a Concept».

77 Roy, Skakmat. Politisk islam: Et alternativ for de muslimske samfund?, 50.

78 Mandaville, Islam and Politics, 107.

79 Louër, Sunnis and Shi'a: A Political History of Discord, 49.

80 Ibid., 57.

81 International Crisis Group, «Understanding Islamism».

82 Ibid., i; Louër, Sunnis and Shi'a: A Political History of Discord, 45 .

83 González Mendelejis, «Toward a New Typology of Sunni Jihad»; Stenersen, «Jihadism after the 'Caliphate': Towards a New Typology». 